\title{
Histochemical and Structure-Biological Quantification of Muscle Physiological Properties
}

\author{
Noboru MANABE \\ Graduate School of Agriculture, Kyoto University, \\ Sakyo-ku, Kyoto shi 606-8502
}

\begin{abstract}
Key words : Skeletal muscle, Physiological properties, Histochemical quantification, Nuclear magnetic resonance spectroscopy (NMR), Structure-biological analysis
\end{abstract}

\section{Quantitative Immunohistochemical Method for Assessment of Physiological Properties of Skeletal Muscles \\ Conventional histochemical classification of muscle fiber types}

Histochemical methods for classification of myofiber type have been used to research the physiological properties of skeletal muscles of wild vertebrates (amphibians ${ }^{60.61)}$, reptiles ${ }^{62)}$, birds $^{63)}$, mammals ${ }^{59,118,126,127,129,131)}$, etc.) and experimental animals ${ }^{1-3,103\rangle}$. The histochemical myofiber type composition of each skeletal muscle reflects its function in locomotion and energy metabolism ${ }^{10,11,13,55,99,100,120)}$. Many techniques have been developed for evaluation of meat quality in carcasses of farm animals, e.g. ultrasonography, fiber-optic spectrophotometry, etc. ${ }^{36-43)}$. Histochemical myofiber types have been investigated in domestic fowls (chickens ${ }^{44,46-51,53,92-96,119)}$, Guinea fowls ${ }^{69}$ ), etc. ) and animals ( pigs ${ }^{8,34,45,97)}$, cattle $e^{9,24-26,32,62,64,67,68,98,112-116)}$, sheep ${ }^{109-111,121,128,130)}$, goats $^{33,80,81,122-125,132,133)}$, horses ${ }^{124,125)}$, etc.), and myofiber classification is considered to be es- sential for precise evaluation of meat quality based on its physiological properties ${ }^{14.21 .54 .85,115)}$. For instance, lipids are stored mainly in type I fibers (slow-twitch oxidative type ; fibers containing slow myosin isoforms) and in some type IIA fibers (fast-twitch oxidative type) in pigs $^{19)}$ and cattle ${ }^{166)}$, and lipid content is related to the shear force of the meat ${ }^{20\rangle}$. Histochemical myofiber classification techniques have been used to study the postnatal changes in muscle properties ${ }^{13,17,120)}$, the effects of diet on muscle characteristics ${ }^{14.56)}$, differences in myofiber properties in breeds ${ }^{32,64}$, and the effects of obesity ${ }^{66,71)}$, hormones and drugs $^{92,97,98)}$. In pigs, muscle fiber type influences heat-induced aggregation of porcine salt -soluble protein, and therefore different processing treatments should be used based on fiber type for optimum quality of meat products $^{107)}$. In Japanese Black cattle, the composition of muscle fiber types is related to marbling score ${ }^{24-26,48,523}$, which is the most important parameter of meat quality in Japan. The muscle fiber type distribution can be altered by diet in growing calves ${ }^{56)}$ and also by

骨格能生理学的特性の定量組織化学および構造生物学的解析に関する研究：真鍋 昇（京都大学大学院農学研究 科，京都市左京区 606-8502) 


\section{MANABE}

excise in sheep ${ }^{133)}$. Thus, the study of the physiological properties of muscle fibers plays an important role in breeding and feeding of meat-producing domestic animals.

Muscle fibers are not static structures but represent versatile entities which adapt to altered functional demands, hormonal signals and changes in neural input ${ }^{99.100)}$. Their dynamic nature makes it difficult to categorize them into distinct units. Therefore, applying any type of rigid structural and functional confines results in an oversimplification which does not take into account the plasticity of phenotypic expression. However, histochemical myofiber typing is an extremely useful tool in many fields of muscle physiology. Classification schemes have helped to define the functional, metabolic and molecular properties of muscle fibers selected on the basis of their histochemical appearance. Under such conditions, certain muscle fiber populations with similar functional properties and molecular profiles may be delineated, e.g. fast- and slowtwitch myofibers, and oxidative and glycolytic myofibers ${ }^{99,100)}$. Major myofiber types, e.g. type I, type IIA and type IIB, represent large groups of muscle fibers displaying similar phenotypes (Table 1). Such groups reflect stable programs or stages of gene expression with preferential combinations of sarcoplasmic and myofibrillar protein isoforms ${ }^{6.16-18,28-31,101,106,108,134,135)}$ for example fast- and slow-myosins. More- over, they are the direct result of predominant patterns of functional demand and neuromuscular activity ${ }^{100)}$. Myofibers within a particular group may show similar structural and functional properties, but the most similar muscle fibers will be those within the same motor unit. Theoretically, there will be at least as many fiber types as there are motor units in a muscle. Within a muscle, a myofiber type may exhibit a continuum of structural and functional properties which overlap with those of other fiber types. As increasing numbers of different muscles and species are investigated and more refined high -resolution techniques are developed and applied, the full extent of cellular and molecular diversity of skeletal muscle should become ev. ident. Histochemical myofiber classification schemes depend upon subjective evaluation and are limited by the restricted resolution of the methods applied ${ }^{10,11,13,55,99,100,120)}$. Only a small number of major myofiber types can be discriminated by qualitative histochemical methods. Nevertheless, histochemical myofiber typing has proven useful in numerous studies concerned with structure function relationships in normal and pathological muscles ${ }^{100)}$.

Classically, two different enzy me-histochemical approaches allow for the separation of myofiber types ${ }^{10,11,13,55,99,100,120)}$. (1) One method is based upon myofibrillar myosin adenosine

Table 1. Histochemical characteristics of myofiber types in the skeletal muscles of farm animals

\begin{tabular}{llccccc}
\hline $\begin{array}{c}\text { Myofiber } \\
\text { types }\end{array}$ & $\begin{array}{c}\text { Anti-fast-myosin } \\
\text { antibody }\end{array}$ & $\begin{array}{c}\text { Acid-stable myosin } \\
\text { ATPase }^{\mathrm{a}}\end{array}$ & $\begin{array}{c}\text { Alkali-stable myosin } \\
\text { ATPase }^{\mathrm{b}}\end{array}$ & SDH $^{\mathrm{c}}$ & NADH-TR $^{\mathrm{d}}$ & PhR $^{\mathrm{s}}$ \\
\hline I & Negative & $++++^{\prime}$ & - & ++++ & ++++ & $-/+$ \\
II A & Positive & - & ++++ & ++++ & ++++ & +++ \\
II B & Positive & - & ++++ & + & + & ++++ \\
\hline
\end{tabular}

"Preincubation at $\mathrm{pH} 4.3$.

${ }^{b}$ Preincubation at $\mathrm{pH} 10.5$.

"Succinate dehydrogenase.

${ }^{\mathrm{d}}$ Reduced nicotinamide adenine dinucleotide-tetrazoliurn reductase.

${ }^{\mathrm{e}} \alpha$-Glycogen phosphorylase.

${ }^{\dagger}$ Enzyme activities : - , unreactive ; + , weak ; +++ , strong $;++++$, very strong. 
triphosphatase (ATPase) activity and the other upon reference enzymes of anaerobic and aerobic energy metabolism. The initial distinction of two myofibrillar myosin ATPase-based fiber types, i.e. type I and type II, was made possible by the use of a histochemical assay for ATPase activity (Table 1). Shortly thereafter, it was demonstrated that fast and slow skeletal muscles contain myosins differing in their specific actin-activated and $\mathrm{Ca}^{2+}$-dependent ATPase activities and that this is correlated with differences in speed of contraction $^{6,16-18,28,57,58,85,102)}$. It became clear that the histochemical differences in the activity of myosin ATPase between type I and type II fibers correspond to differences in contractile properties. Subsequently, differences in proteolytic fragments and antigenicity suggested the existence of myosin heavy chain isoforms ${ }^{106)}$. (2) Different types of muscle fibers have also been distinguished on the basis of histochemical reactions for enzymes of aerobic oxidative metabolism, e.g. succinate dehydrogenase (SDH), cytochrome oxidase, nicotinamide adenine dinucleotide (NADH) tetrazolium reductase, etc. ${ }^{100}$. Two major myofiber types derived from differences in these enzyme activities basically reflect differences in mitochondrial content (high and low), and therefore are primarily related to differ. ences in aerobic oxidative potential, Myofiber types can also be delineated histochemically by the inverse relationship between the activity of glycolytic metabolic enzymes, e.g. glycogen phosphorylase, mitochondrial glycerophosphate dehydrogenase, etc., and the activities of the enzymes involved in aerobic oxidative metabolism. As described above, this conventional histochemical classification of myofibers have been used for qualitative analysis of the physiological properties of skeletal muscles in farm animals.

\section{Histomorphometrical analysis of skeletal muscles}

Histomorphometry is a conventional quanti- tative method for assessment of skeletal muscle properties ${ }^{12,15,76,78,81,85)}$. As described above, the physiological characteristics of mammalian skeletal muscles have been assessed by histochemical and biochemical methods. The muscle fibers can be classified into three major myofiber types, and then further into some minor types according to the intensity of enzyme activity demonstrated histochemically in individual myofibers. The cross sectional area of each myofiber type in muscle samples was measured by morphometrical techniques using a computer-aided automatic image analyzer ${ }^{12,15,76,78,81,85)}$. The Division of Computer Research and Technology of the National Institute of Health (NIH), in USA has made the image processing application NIH Image available without charge. NIH Image is available for the Macintosh and also for IBM - compatible computers running Windows. NIH Image can be downloaded by anonymous ftp from ftp://zippy.nimh.nih. gov/pub/nih-image/. Additional programs, macros, plug-ins, complete source code, etc., are available from the NIH Web site (http:/) rsb.info.nih.gov/nih-image/). Detailed questions regarding the application will be answered by Dr. Mark Vivino (mvivino@helix. nih.gov). NIH Image supports many standard image processing functions including contrast enhancement, density profiling, smoothing, sharpening, edge detection, median filtering and spatial convolution with user defined kernels. It can be used to measure area, mean, centroid, perimeter, etc. of user-defined regions of interest, and also performs automated analy. sis. As image processing and analysis methods differ among different programs, it is difficult to compare image analysis data presented by different research groups. If all in. vestigators used the same image processing and analysis program, e.g. NIH Image, the image data from different laboratories would be compatible with each other. An example of image analysis of goat myofibers performed 
using NIH Image is shown in Fig. 1. NIH Image running on a Power Macintosh 9600/OS 8.0 computer with $672 \mathrm{MB}$ of RAM was used to perform automated analysis. As reported previously ${ }^{76,78,81,85)}$, frozen serial sections of goat skeletal muscles were incubated for enzyme histochemical analysis of myosin ATPase, succinate dehydrogenase, NADH tetrazolium reductase and $\alpha$-glycogen phosphorylase activities, and stained immunohistochemically using a monoclonal antibody against fastmyosin. Serial sections stained for SDH and fast-myosin were photographed, and then these photographs were scanned into a Power Macintosh computer (Fig. $1 \mathrm{~A}$ and $\mathrm{B}$, respectively) using a film scanner. Histochemical reactions were automatically divided into two classes, i.e. negative and positive (binarization) (Fig. $1 \mathrm{C}$ and D, respectively), using NIH Image on a Power Macintosh computer. Myofibers (at least 500 fibers/section; three sections/ muscle) were classified into three major types according to differences in reactivity for the enzymes and with the antibody (Fig. 1E). Species-specific myofiber types were reported in the skeletal muscles of ruminants ${ }^{109-111}$. Type Ib fibers which showed weak SDH activity and were negative for fast-myosin were observed in the goat skeletal muscles and were categorized as type I myofibers for sim. plicity ${ }^{85)}$. The numbers of fibers of each type and the transverse area of each myofiber in the sections were automatically measured using the image analysis system (Table 2), and then the proportions of each myofiber type were calculated (Table 3$)^{76.78,81.85)}$.

\section{Immunohistochemical quantitative analysis of skeletal muscles}

Conventional histomorphometrical techniques preserve the muscle structure and require very small samples (thin sections mounted on glass slides), but they cannot provide information regarding the precise quantitative properties of the skeletal muscles ${ }^{76,78,81,85)}$. Even with use of a automated image analysis system as described above, analysis of the muscle properties still requires in the use of histochemical techniques and is time-consuming. The pyrophosphoric acid polyacrylamide gel electrophoresis method ${ }^{16-18,76,78,81,85)}$ allows precise quantitative evaluation but requires large tissue samples and the muscle structure is destroyed because samples must be homogenized. For example, electrophoresis has been used to analyze myosin isoforms, the major contractile components which determine the contractile properties of muscle fibers ${ }^{28)}$, and at least $100 \mathrm{mg}$ of wet tissue was required ${ }^{76,78,81,85)}$. Myosin is an asymmetrical, hexameric protein consisting of four light chains (approximately $20 \mathrm{kDa}$ each) and two heavy chains (approximately $200 \mathrm{kDa}$ each) $)^{6,16-18,28-31,57,58,106,134,135)}$. This ubiquitous protein, found in both muscle and nonmuscle cells, makes up the largest part of the contractile apparatus in skeletal muscle fibers. The two myosin heavy chains intertwine at the carboxyl terminus forming an $\alpha$ helical coiled coil (the rod part). The amino terminus of each heavy chain forms a globular head region such that each holomyosin contains two heads. The rod is responsible for the aggregation of myosin molecules into bipolar thick filaments, whereas the head region is the site of ATPase activity and actin binding. Myofibers contain at least two types of myosin. Fast-myosin is the major contractile component that determines the contractile properties of muscle fibers, and thus is a key protein for their precise evaluation. Fast-myosin content in the skeletal muscles have been measured by conventional biochemical electrophoretic methods. Recently, Picard et al. ${ }^{102)}$ reported the use of an enzyme-linked immunosorbent assay (ELISA) with a monoclonal antibody specific for type I myosin heavy chain (slowmyosin) to quantitatively assess the contractile properties of bovine skeletal muscles. Their biochemical ELISA method was sensitive sufficiently for precise measurement and was a simple procedure compared with conventional 

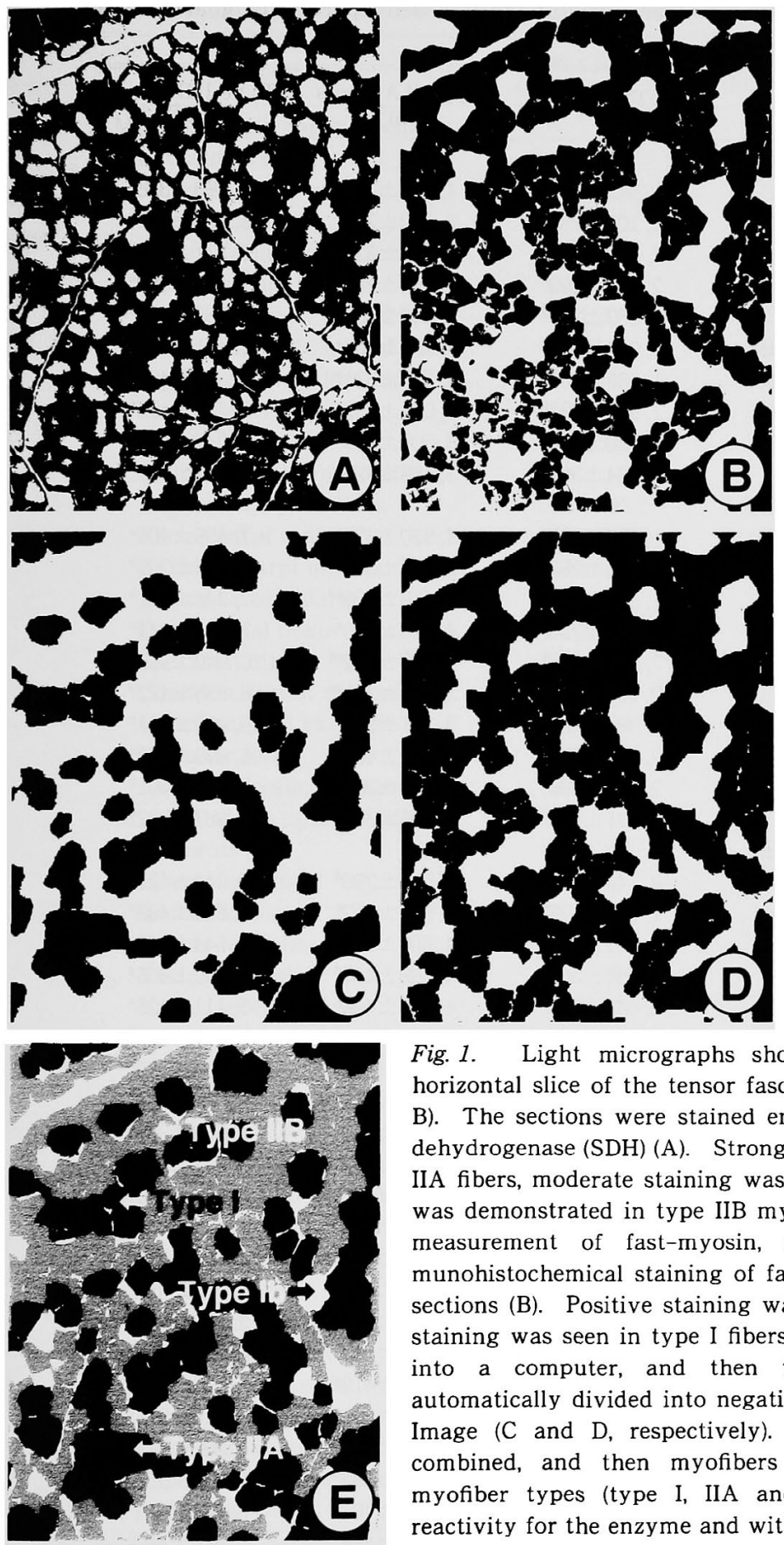

Fig. 1. Light micrographs showing serial cross-sections from a horizontal slice of the tensor fasciae latae muscle of the goat (A and B). The sections were stained enzyme histochemically for succinate dehydrogenase (SDH) (A). Strong staining was observed in type I and IIA fibers, moderate staining was seen in type Ib, and weak staining was demonstrated in type IIB myofibers. After immunohistochemical measurement of fast-myosin, an additional procedure for immunohistochemical staining of fast-myosin was applied to the serial sections (B). Positive staining was observed in type II fibers, but no staining was seen in type I fibers. These photographs were scanned into a computer, and then the histochemical reactions were automatically divided into negative and positive reactions using $\mathrm{NIH}$ Image (C and D, respectively). These images were automatically combined, and then myofibers were classified into three major myofiber types (type I, IIA and IIB) according to differences in reactivity for the enzyme and with the antibody $(\mathrm{E})$. In goat muscles, species-specific type Ib myofibers with moderate SDH activity were observed, and they were finally classified as type I. 


\section{MANABE}

Table 2. Transverse area of myofiber types in the mid-belly portion of goat skeletal muscles

\begin{tabular}{|c|c|c|c|}
\hline Muscle & $\begin{array}{l}\text { Type I fibers } \\
\left(\mu \mathrm{m}^{2}\right)\end{array}$ & $\begin{array}{l}\text { Type Il A fibers } \\
\left(\mu \mathrm{m}^{2}\right)\end{array}$ & Type $\underset{\left(\mu \mathrm{m}^{2}\right)}{\mathrm{z}}$ fibers \\
\hline \multicolumn{4}{|l|}{ Muscles of the upper forelimb } \\
\hline Latissimus dorsi & $1,943 \pm 169^{a}$ & $4,234 \pm 266^{\mathbf{a}}$ & $7,363 \pm 368^{a}$ \\
\hline Superficial pectoralis & $2,101 \pm 232^{\mathrm{a}}$ & $3,120 \pm 282^{b}$ & $5,997 \pm 357^{b}$ \\
\hline Deep pectoralis & $2,413 \pm 185^{b}$ & $3,326 \pm 321^{\mathrm{b}}$ & $6,011 \pm 302^{b}$ \\
\hline Tensor faciae antebrachii & $2,048 \pm 199^{\circ}$ & $4,254 \pm 282^{\mathrm{a}}$ & $7,126 \pm 380^{\mathrm{a}}$ \\
\hline Cleidobrachialis & $1,857 \pm 201^{a}$ & $3,940 \pm 336^{a}$ & $6,557 \pm 522^{\mathrm{ab}}$ \\
\hline Triceps brachii, lateral head & $2,014 \pm 201^{a}$ & $4,085 \pm 302^{a}$ & $7,451 \pm 874^{a}$ \\
\hline Triceps brachii, medial head & $1,662 \pm 204^{c}$ & $3,684 \pm 331^{\mathrm{ac}}$ & $6,358 \pm 481^{b}$ \\
\hline Triceps brachii, long head & $1,984 \pm 331^{2}$ & $4,014 \pm 332^{\mathrm{a}}$ & $7,205 \pm 484^{\mathrm{a}}$ \\
\hline Biceps brachii & $2,788 \pm 303^{d}$ & $3,308 \pm 299^{b}$ & $6,047 \pm 441^{b}$ \\
\hline Brachialis & $3,054 \pm 387^{d}$ & $3,406 \pm 526^{b c}$ & $5,870 \pm 558^{b}$ \\
\hline \multicolumn{4}{|l|}{ Muscles of the lower forelimb } \\
\hline Extensor carpi radialis & $1,894 \pm 158^{a}$ & $4,520 \pm 322^{d}$ & $7,455 \pm 405^{\mathrm{a}}$ \\
\hline Flexor carpi radialis & $2,524 \pm 252^{\text {bd }}$ & $3,478 \pm 362^{b c}$ & $6,325 \pm 236^{\mathrm{b}}$ \\
\hline Extensor carpi ulnaris & $1,944 \pm 221^{a}$ & $4,418 \pm 298^{\mathrm{ad}}$ & $7,244 \pm 581^{\mathrm{a}}$ \\
\hline Flexor carpi ulnaris & $1,887 \pm 220^{a}$ & $4,218 \pm 295^{a}$ & $7,401 \pm 344^{a}$ \\
\hline Deep digital flexor & $2,210 \pm 205^{a}$ & $3,655 \pm 322^{\mathrm{ac}}$ & $6,940 \pm 350^{\mathrm{a}}$ \\
\hline Sperficial digital flexor & $2,754 \pm 381^{d}$ & $3,401 \pm 281^{\mathrm{bc}}$ & $6,335 \pm 422^{b}$ \\
\hline Common digital extensor & $2,984 \pm 415^{d}$ & $3,321 \pm 365^{b}$ & $5,968 \pm 584^{b}$ \\
\hline Lateral digital extensor & $2,018 \pm 254^{a}$ & $3,804 \pm 409^{a}$ & $6,875 \pm 560^{a}$ \\
\hline Pronator teres & $2,897 \pm 336^{\mathrm{d}}$ & $3,059 \pm 387^{b}$ & $5,940 \pm 491^{b}$ \\
\hline Adductor pollicis longus & $3,011 \pm 425^{d}$ & $3,266 \pm 369^{b}$ & $6,387 \pm 522^{b}$ \\
\hline \multicolumn{4}{|l|}{ Muscles of the upper hindlimb } \\
\hline Sartorius & $2,144 \pm 224^{a}$ & $4,519 \pm 295^{d}$ & $7,244 \pm 422^{\mathrm{a}}$ \\
\hline Biceps femoris & $2,201 \pm 276^{a}$ & $4,908 \pm 462^{e}$ & $6,669 \pm 438^{a}$ \\
\hline Rectus femoris & $2,011 \pm 322^{\mathrm{a}}$ & $4,885 \pm 351^{\mathrm{e}}$ & $7,544 \pm 520^{\mathrm{a}}$ \\
\hline Vastus lateralis & $1,957 \pm 306^{a}$ & $4,598 \pm 435^{d}$ & $6,977 \pm 455^{a}$ \\
\hline Vastus medialis & $2,044 \pm 269^{a}$ & $4,925 \pm 406^{e}$ & $7,411 \pm 426^{a}$ \\
\hline Vastus intermedialis & $3,804 \pm 334^{e}$ & $3,994 \pm 501^{\mathrm{a}}$ & $6,097 \pm 328^{b}$ \\
\hline Adductores & $2,620 \pm 318^{\text {bd }}$ & $3,694 \pm 336^{\mathrm{ac}}$ & $6,588 \pm 362^{\mathrm{ab}}$ \\
\hline Semitendinosu & $1,987 \pm 199^{a}$ & $4,075 \pm 433^{a}$ & $6,336 \pm 457^{d}$ \\
\hline Semimembranosus & $2,158 \pm 306^{a}$ & $3,997 \pm 336^{\mathrm{a}}$ & $6,654 \pm 380^{\mathrm{ab}}$ \\
\hline Pectimeus & $3,011 \pm 247^{d}$ & $4,087 \pm 462^{\mathrm{a}}$ & $5,877 \pm 531^{b}$ \\
\hline Gracilis & $2,698 \pm 305^{d}$ & $4,478 \pm 455^{\text {ad }}$ & $5,960 \pm 526^{b}$ \\
\hline \multicolumn{4}{|l|}{ Muscles of the lower hindlimb } \\
\hline Gastrocnemius, lateral head & $2,403 \pm 131^{b}$ & $3,460 \pm 409^{\mathrm{bc}}$ & $4,392 \pm 368^{c}$ \\
\hline Gastrocnemius, medial head & $1,874 \pm 234^{a}$ & $3,788 \pm 351^{\text {ac }}$ & $5.966 \pm 411^{b}$ \\
\hline Soleus & $2,855 \pm 406^{d}$ & $3,604 \pm 350^{\mathrm{ac}}$ & $3,969 \pm 422^{\circ}$ \\
\hline Cranial tibialis & $2,622 \pm 252^{\text {bd }}$ & $3,478 \pm 362^{\mathrm{bc}}$ & $6,325 \pm 236^{b}$ \\
\hline Long digital extensor & $1,955 \pm 321^{2}$ & $4,155 \pm 419^{a}$ & $6,325 \pm 408^{b}$ \\
\hline Lateral digital extensor & $3.014 \pm 441^{\mathrm{d}}$ & $3,965 \pm 501^{a}$ & $4,115 \pm 521^{c}$ \\
\hline Peroneus longus & $2,877 \pm 258^{d}$ & $3,448 \pm 342^{\mathrm{bc}}$ & $5,988 \pm 479^{b}$ \\
\hline Deep digital flexor & $2,322 \pm 252^{2 b}$ & $3,478 \pm 362^{\mathrm{bc}}$ & $6,058 \pm 236^{\mathrm{b}}$ \\
\hline Superficial digital flexor & $2,031 \pm 155^{a}$ & $3,684 \pm 461^{\text {ac }}$ & $6,448 \pm 363^{b}$ \\
\hline Popliteus & $2,541 \pm 332^{\text {bd }}$ & $3,804 \pm 455^{a}$ & $5.840 \pm 462^{b}$ \\
\hline
\end{tabular}

a, b,c,d,e : Means followed by different superscripts differed significantly $(P<0,05)$. 


\section{Quantification of Muscle Properties}

Table 3. Populations of myofiber types in the mid-belly portion of goat skeletal muscles

\begin{tabular}{|c|c|c|c|}
\hline Muscle & $\begin{array}{l}\text { Type I fibers } \\
\text { (fibers } / \mathrm{mm}^{2} \text { ) }\end{array}$ & $\begin{array}{l}\text { Type II A fibers } \\
\text { (fibers } / \mathrm{mm}^{2} \text { ) }\end{array}$ & $\begin{array}{l}\text { Type II B fibers } \\
\text { (fibers } / \mathrm{mm}^{2} \text { ) }\end{array}$ \\
\hline \multicolumn{4}{|l|}{ Muscles of the upper forelimb } \\
\hline Latissimus dorsi & $515 \pm 26^{a}$ & $236 \pm 22^{a}$ & $136 \pm 43^{a}$ \\
\hline Superficial pectoralis & $476 \pm 24^{a}$ & $321 \pm 19^{b}$ & $167 \pm 33^{a}$ \\
\hline Deep pectoralis & $414 \pm 33^{b}$ & $301 \pm 39^{b}$ & $166 \pm 33^{a}$ \\
\hline Tensor faciae antebrachii & $488 \pm 14^{\mathrm{a}}$ & $235 \pm 18^{a}$ & $140 \pm 39^{a}$ \\
\hline Cleidobrachialis & $539 \pm 16^{\circ}$ & $254 \pm 16^{a}$ & $153 \pm 21^{a}$ \\
\hline Triceps brachii, lateral head & $497 \pm 20^{a}$ & $245 \pm 17^{2}$ & $134 \pm 30^{a}$ \\
\hline Triceps brachii, medial head & $602 \pm 67^{c}$ & $271 \pm 29^{\mathrm{ab}}$ & $157 \pm 29^{a}$ \\
\hline Triceps brachii, long head & $504 \pm 24^{a}$ & $249 \pm 32^{\mathrm{a}}$ & $139 \pm 36^{a}$ \\
\hline Biceps brachii & $359 \pm 57^{d}$ & $302 \pm 25^{b}$ & $165 \pm 25^{a}$ \\
\hline Brachialis & $327 \pm 31^{d}$ & $294 \pm 26^{b}$ & $170 \pm 26^{\mathrm{a}}$ \\
\hline \multicolumn{4}{|l|}{ Muscles of the lower forelimb } \\
\hline Extensor carpi radialis & $528 \pm 19^{a}$ & $221 \pm 31^{a}$ & $134 \pm 41^{a}$ \\
\hline Flexor carpi radialis & $396 \pm 36^{b}$ & $288 \pm 42^{b}$ & $158 \pm 24^{\mathrm{a}}$ \\
\hline Extensor carpi ulnaris & $514 \pm 15^{\mathrm{a}}$ & $226 \pm 31^{a}$ & $138 \pm 34^{\mathrm{a}}$ \\
\hline Flexor carpi ulnaris & $530 \pm 31^{a}$ & $237 \pm 19^{a}$ & $135 \pm 33^{a}$ \\
\hline Deep digital flexor & $452 \pm 46^{\mathrm{ab}}$ & $274 \pm 41^{a b}$ & $144 \pm 31^{a}$ \\
\hline Sperficial digital flexor & $363 \pm 57^{\text {bd }}$ & $294 \pm 15^{b}$ & $158 \pm 25^{\mathrm{a}}$ \\
\hline Common digital extensor & $335 \pm 22^{\mathrm{d}}$ & $301 \pm 28^{b}$ & $168 \pm 27^{a}$ \\
\hline Lateral digital extensor & $496 \pm 19^{3}$ & $263 \pm 34^{\mathrm{ab}}$ & $145 \pm 24^{\mathrm{a}}$ \\
\hline Pronator teres & $345 \pm 30^{d}$ & $327 \pm 36^{b}$ & $168 \pm 24^{\mathrm{a}}$ \\
\hline Adductor pollicis longus & $332 \pm 15^{d}$ & $306 \pm 20^{\circ}$ & $157 \pm 20^{\mathrm{a}}$ \\
\hline \multicolumn{4}{|l|}{ Muscles of the upper hindlimb } \\
\hline Sartorius & $466 \pm 21^{\mathrm{ab}}$ & $221 \pm 18^{a}$ & $138 \pm 35^{a}$ \\
\hline Biceps femoris & $454 \pm 25^{\mathrm{ab}}$ & $204 \pm 22^{a}$ & $150 \pm 30^{a}$ \\
\hline Rectus femoris & $497 \pm 14^{\mathrm{a}}$ & $205 \pm 14^{a}$ & $133 \pm 28^{a}$ \\
\hline Vastus lateralis & $511 \pm 18^{\mathrm{a}}$ & $217 \pm 29^{a}$ & $143 \pm 33^{a}$ \\
\hline Vastus medialis & $489 \pm 23^{a}$ & $203 \pm 35^{a}$ & $135 \pm 27^{a}$ \\
\hline Vastus intermedialis & $263 \pm 45^{\circ}$ & $250 \pm 30^{\mathrm{ab}}$ & $164 \pm 15^{a}$ \\
\hline Adductores & $382 \pm 44^{\text {bd }}$ & $271 \pm 38^{\mathrm{ab}}$ & $152 \pm 27^{a}$ \\
\hline Semitendinosu & $503 \pm 16^{\mathrm{a}}$ & $245 \pm 20^{\mathrm{a}}$ & $158 \pm 36^{a}$ \\
\hline Semimembranosus & $463 \pm 8^{a b}$ & $250 \pm 43^{a b}$ & $150 \pm 25^{a}$ \\
\hline Pectimeus & $332 \pm 37^{d}$ & $245 \pm 22^{\mathrm{a}}$ & $170 \pm 21^{\mathrm{a}}$ \\
\hline Gracilis & $371 \pm 23^{\text {bd }}$ & $223 \pm 32^{\mathrm{a}}$ & $168 \pm 9^{a}$ \\
\hline \multicolumn{4}{|l|}{ Muscles of the lower hindlimb } \\
\hline Gastrocnemius, lateral head & $416 \pm 21^{b}$ & $289 \pm 26^{\mathrm{b}}$ & $228 \pm 27^{b}$ \\
\hline Gastrocnemius, medial head & $534 \pm 22^{\mathrm{a}}$ & $264 \pm 37^{\mathrm{ab}}$ & $168 \pm 22^{a}$ \\
\hline Soleus & $350 \pm 60^{\text {bd }}$ & $277 \pm 36^{\mathrm{ab}}$ & $252 \pm 20^{\circ}$ \\
\hline Cranial tibialis & $381 \pm 40^{\text {bd }}$ & $288 \pm 16^{\mathrm{ab}}$ & $158 \pm 29^{a}$ \\
\hline Long digital extensor & $512 \pm 16^{\mathrm{a}}$ & $241 \pm 19^{\mathrm{a}}$ & $158 \pm 33^{\mathrm{a}}$ \\
\hline Lateral digital extensor & $332 \pm 47^{d}$ & $252 \pm 32^{\mathrm{ab}}$ & $243 \pm 18^{b}$ \\
\hline Peroneus longus & $348 \pm 27^{d}$ & $290 \pm 28^{b}$ & $167 \pm 33^{a}$ \\
\hline Deep digital flexor & $431 \pm 46^{\mathrm{b}}$ & $288 \pm 24^{b}$ & $165 \pm 43^{a}$ \\
\hline Superficial digital flexor & $492 \pm 17^{a}$ & $271 \pm 32^{\mathrm{ab}}$ & $155 \pm 36^{a}$ \\
\hline Popliteus & $394 \pm 27^{b}$ & $263 \pm 38^{a b}$ & $171 \pm 31^{\mathrm{a}}$ \\
\hline
\end{tabular}

a,b,c,d,e : Means followed by different superscripts differed significantly $(\mathrm{P}<0.05)$. 
electrophoresis techniques, but the tissue structure was also completely destroyed. A new sensitive method for quantitative analysis in histological muscle sections, in which the structure can be well-preserved, is needed for quantitative evaluation of the properties of skeletal muscles.

We have developed a novel method for quantification of fast-myosin, which is a key protein for precise evaluation of the contractile properties of skeletal muscle, in sections mounted on glass slides ${ }^{76,78,80,81,85)}$. A flow diagram of this histochemical micromethod is shown in Fig. 2. Frozen muscle sections mounted on glass slides are used in this technique as analogues of the antigen-precoated wells of ELISA plates. Using frozen sections of the masseter and gastrocnemius muscles from five mammals (adult Holstein-Friesian cows, female Berkshire pigs, female Saanen goats, male Sprague-Dawley rats and female Japanese White rabbits), we demonstrated the usefulness of our immunohistochemical method for the quantification of fast-myosin

\section{Preparation of direct standard curve}

1. Coat the wells of the ELISA plate with purified fast-myosin standard.

2. Incubate with first antibody (mouse anti-rabbit skeletal fastmyosin monoclonal IgG antibody; $1 / 400$ dilution) $\left(4^{\circ} \mathrm{C}, 18 \mathrm{~h}\right)$.

3. Transfer the supernatant to ELISA plate precoated with fastmyosin (continue on II-2).

4. Rinse ( $x 5,5$ min each), and then incubate with second antibody (horseradish peroxidase-conjugated goat anti-mouse IgG antibody; $1 / 400$ dilution) $\left(37^{\circ} \mathrm{C}, 2 \mathrm{~h}\right)$.

5. Rinse (x5, $5 \mathrm{~min}$ each), and then incubate with chromogenic substrate solution (PBS containing $3 \mathrm{mM} 4$ aminoantipyrine, $30 \mathrm{mM}$ phenol and $\left.2 \mathrm{mM} \mathrm{H}_{2} \mathrm{O}_{2}\right)\left(37^{\circ} \mathrm{C}, 1 \mathrm{~h}\right)$.

8. Stop the reaction with $1 \mathrm{M} \mathrm{NaN3}$ solution, and then determine the $O D$ at $450 \mathrm{~nm}$.

\section{Preparation of indirect standard curve}

1. Incubate fast-myosin standard solution with first antibody.

2. Transfer the supernatant of I-2 (continue from I-2) and II-1 to ELISA plate precoated with fast-myosin.

3. Incubate, rinse and then incubate with second antibody.

4. Rinse, and then incubate with chromogenic substrate solution.

5. Stop the reaction, and then determine the OD at $450 \mathrm{~nm}$.

III. Measurement of fast-myosin content in sections

1. Preincubate with normal goat serum, rinse and then incubate with first antibody.

2. Rinse and inhibit the endogenous peroxidase activity.

3. Rinse, and then incubate with second antibody.

4. Rinse, and then incubate with chromogenic substrate solution.

5. Stop the reaction, and then determine the $O D$ at $450 \mathrm{~nm}$ (continue on IV-1).

IV. Measurement of total protein content in sections

1. Remove the antigen-antibody complex.

2. Rinse and stain with sirius red F3BA and fast green FCF.

3. Rinse, extract colors and then read at 540 and $630 \mathrm{~nm}$.

Fig. 2. Flow diagram of immunohistochemical measurement of fast-myosin in skeletal muscle sections. 
responsible for the contractile properties of muscle fibers ${ }^{78}$. Then, we examined the contents of fast-myosin in different portions of the limb muscles of female Saanen goats to determine the usefulness of this micromethod for evaluating the physiological properties of muscle and meat quality (Table 4$)^{76,81)}$. This immunohistochemical method based on the principle of the ELISA technique requires only small frozen sections for precise quantification, and the tissue structure is completely preserved. This preservation is important for precise evaluation of the physiological properties of skeletal muscles. Furthermore, even after measurement, the localization of fast-myosin in the tissue sections can be visualized by additional immunohistochemical staining (Fig. 1 B). We have developed double measurement method by which fast-myosin and type I collagen levels can be assessed on the same sections (in preparation). A more complete analysis of fast-myosin isoform contents in the skeletal muscles from domestic animals may lead to a better understanding of their physiological properties and meat quality.

On immunohistochemical micromethod, based on the principle of the ELISA technique, requires only one frozen section mounted on a glass slide for precise quantification, and the tissue structure is completely preserved. This method is sufficiently sensitive for estimation of the quantity of fast-myosin isoforms using frozen tissue sections. Conventionally, the intensity of immunohistochemical staining has been evaluated by subjective methods, for example by scoring. However, histological scoring is not quantitative, and the results of such scoring differ among different observers. The intensity of immunoreactivity of a target substance in frozen tissue sections can be quantified by our immunohistochemical micromethod. This novel micromethod can be used for measurement of other proteins, e.g. extracellular matrix proteins, actin, myoglobin,
Table 4. Fast-myosin level assessed by immunohistochemical method in the mid-belly portion of goat skeletal muscles

\begin{tabular}{|c|c|}
\hline Muscle & $\begin{array}{l}\text { Fast-myosin } \\
\text { (mg/g of total protein) }\end{array}$ \\
\hline \multicolumn{2}{|l|}{ Muscles of the upper forelimb } \\
\hline Latissimus dorsi & $178 \pm 18^{\mathrm{a}}$ \\
\hline Superficial pectoralis & $169 \pm 16^{a}$ \\
\hline Deep pectoralis & $145 \pm 12^{\mathrm{b}}$ \\
\hline Tensor faciae antebrachii & $182 \pm 21^{\mathbf{a}}$ \\
\hline Cleidobrachialis & $194 \pm 19^{a}$ \\
\hline Triceps brachii, lateral head & $205 \pm 18^{a}$ \\
\hline Triceps brachii, medial head & $15 \pm 4^{c}$ \\
\hline Triceps brachii, long head & $189 \pm 14^{a}$ \\
\hline Biceps brachii & $51 \pm 6^{d}$ \\
\hline Brachialis & $87 \pm 12^{e}$ \\
\hline \multicolumn{2}{|l|}{ Muscles of the lower forelimb } \\
\hline Extensor carpi radialis & $186 \pm 12^{a}$ \\
\hline Flexor carpi radialis & $141 \pm 15^{b}$ \\
\hline Extensor carpi ulnaris & $192 \pm 12^{a}$ \\
\hline Flexor carpi ulnaris & $174 \pm 15^{a}$ \\
\hline Deep digital flexor & $152 \pm 10^{b}$ \\
\hline Sperficial digital flexor & $41 \pm 6^{\mathrm{d}}$ \\
\hline Common digital extensor & $148 \pm 13^{b}$ \\
\hline Lateral digital extensor & $142 \pm 17^{6}$ \\
\hline Pronator teres & $128 \pm 12^{\text {be }}$ \\
\hline Adductor pollicis longus & $145 \pm 17^{\mathrm{b}}$ \\
\hline \multicolumn{2}{|l|}{ Muscles of the upper hindlimb } \\
\hline Sartorius & $197 \pm 13^{a}$ \\
\hline Biceps femoris & $193 \pm 16^{a}$ \\
\hline Rectus femoris & $201 \pm 14^{\mathrm{a}}$ \\
\hline Vastus lateralis & $208 \pm 21^{a}$ \\
\hline Vastus medialis & $184 \pm 11^{3}$ \\
\hline Vastus intermedialis & $24 \pm 8^{c}$ \\
\hline Adductores & $112+14^{\text {be }}$ \\
\hline Semitendinosu & $204 \pm 19^{a}$ \\
\hline Semimembranosus & $212 \pm 18^{a}$ \\
\hline Pectimeus & $148 \pm 15^{\mathrm{b}}$ \\
\hline Gracilis & $160 \pm 18^{a}$ \\
\hline \multicolumn{2}{|l|}{ Muscles of the lower hindlimb } \\
\hline Gastrocnemius, lateral head & $205 \pm 10^{a}$ \\
\hline Gastrocnemius, medial head & $184 \pm 16^{\mathrm{a}}$ \\
\hline Soleus & $19 \pm 7^{c}$ \\
\hline Cranial tibialis & $130 \pm 14^{\mathrm{b}}$ \\
\hline Long digital extensor & $201 \pm 21^{a}$ \\
\hline Lateral digital extensor & $74 \pm 9^{e}$ \\
\hline Peroneus longus & $144 \pm 11^{\mathrm{b}}$ \\
\hline Deep digital flexor & $136 \pm 17^{\mathrm{b}}$ \\
\hline Superficial digital flexor & $191 \pm 16^{\mathrm{a}}$ \\
\hline Popliteus & $105 \pm 7^{\text {be }}$ \\
\hline
\end{tabular}

a.b.c.de: Means followed by different superscripts differed significantly ( $P<0.05)$. 
calpain, etc., in histological muscle sections. Thus, this quantitative technique could be used to study the physiological characteristics of muscle that determine meat quality. Furthermore, this technique is available for quantitative analysis of other organs under physiological and pathological conditions. Our previous studies revealed that this immunohistochemical microquantification method is also a useful tool for quantitative histopathological diagnosis in patients and $/$ or experimental animals with hepatic ${ }^{28,69,70,73,79,80,84,86-88)}$, renal ${ }^{75,79,90)}$ and cutaneous ${ }^{91)}$ failure.

\section{Noninvasive Quantitative Assessment of Muscle Energy Metabolism and Catabolism by ${ }^{31} \mathbf{P}$ Nuclear Magnetic Resonance Spectroscopy}

We have developed a ${ }^{\text {al }} \mathrm{P}$ nuclear magnetic resonance $\left({ }^{31} \mathrm{P}\right.$ NMR) spectroscopy method for in vivo measurement of hepatic adenosine triphosphate (ATP) level ${ }^{72,74,83)}$. This in vivo ${ }^{31} \mathrm{P}$ NMR technique is sufficiently sensitive to predict liver damage induced by environmental toxic chemicals ${ }^{23,74)}$ or by ischemic damage $e^{23.89)}$, and to evaluate the improvement of liver function by synthetic drugs and natural medicines ${ }^{83)}$. Recently, we modified this structure biological method for assessment of muscle energy metabolism and catabolism ${ }^{4,5)}$. The process of catabolism in postmortem muscle has been intensively investigated by conventional biochemical methods. However, the destructive nature of these conventional methods inevitably induces the breakdown of high-energy phosphates. Our ${ }^{31} \mathrm{P}$ NMR spectroscopy technique is a useful and powerful tool for investigating tissue metabolism in a noninvasive manner ${ }^{4,5)}$. The NMR method enables us to simultaneously estimate the levels of high-energy phosphates (ATP, adenosine diphosphate: ADP, adenosine monophosphate, etc.), creatine phosphate, inorganic phosphate, sugar phosphates, etc., in a single specimen.
This NMR method also provides information about intracellular $\mathrm{pH}^{4,5)}$. The detailed methodology was confirmed using muscle samples from laboratory animals ${ }^{5}$. In our previous study ${ }^{5)},{ }^{31} \mathrm{P}$ NMR was used to investigate the catabolism of phosphorylated metabolites and the intracellular $\mathrm{pH}$ changes in isolated soleus and extensor digitorum longus (EDL) muscles of rats. These two muscles are typical slowtwitch (type I myofiber-dominant muscle) and fast-twitch muscles (type Il myofiber-dominant muscle), respectively. Both muscles can be dissected out without cutting their myofibers. Although there have been several NMR studies of the relationship between histochemical myofiber type composition and postmortem catabolism, none used muscle specimens that were undamaged during sample preparation or measured high-energy phosphate levels. We estimated the time course of catabolism of phosphorylated metabolites in undamaged rat muscles by means of our noninvasive ${ }^{31} \mathrm{P}$ NMR method. The soleus and the EDL muscles were obtained without any muscle damage. In vivo ${ }^{31} \mathrm{P}$ NMR spectra of these muscles were acquired using a surface coil, and continuous changes in muscle energy metabolism were quantified (Fig. 3). Briefly, each animal was anesthetized by intraperitoneal injection of sodium pentobarbital. During the NMR examination, the animal was maintained in a probe-chamber at a controlled air temperature of $25^{\circ} \mathrm{C}$. ${ }^{31} \mathrm{P}$ NMR spectra were obtained using a wide bore type NMR spectrometer (JNM $\alpha-400$, JEOL, Tokyo, Japan) equipped with a superconducting magnet (9.20 Tesla; Oxford Instruments, Bedford, MA, USA). The animal was mounted on a custom made surface coil probe (two-turns, $2.0 \mathrm{~cm}$ diameter) which was tuned to ${ }^{31} \mathrm{P}$ at 161.7 $\mathrm{MHz}$ and used in conjunction with a ferrite screen composed of strips of computer-tape (Scotch 700 ; Three M Co., St. Louis, MO) to eliminate ${ }^{31} \mathrm{P}$ NMR signals arising from cutaneous tissues. Field homogeneity was 


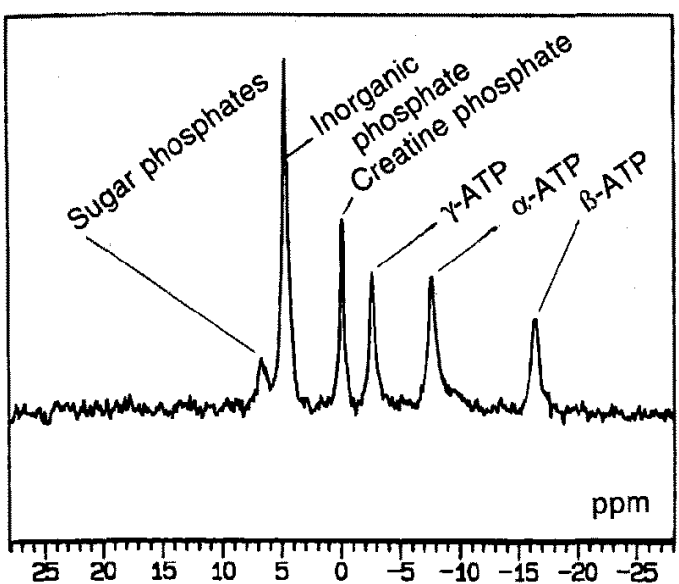

Fig. 3. A representative in vivo ${ }^{31} \mathrm{P}$ NMR spectrum of rat extensor digitorum longus muscle (fast-twitch muscle or type II myofiberdominant muscle). Prominent peaks observed were sugar phosphates, inorganic phosphate, creatine phosphate, nucleotide triphosphates (mainly $\gamma$-ATP, $\alpha$-ATP, and $\beta$-ATP). The $\gamma$-ATP and $\alpha$-ATP signals contained contributions from $\beta$ - and $\alpha-\mathrm{ADP}$, respectively. The signal corresponding to $\beta$-ATP, which has no overlap with other phosphate signals, was used to quantify ATP.

controlled by adjusting shim parameters using the water ${ }^{1} \mathrm{H}$ signal derived from the muscle tissue sample. Acquisition conditions were set as follows to obtain fully relaxed signals : pulse width, $20 \mu \mathrm{sec}$; pulse repetition time, $3.0 \mathrm{~s} ; 200$ scans were accumulated. Thus, it took $10 \mathrm{~min}$ for each measurement. After exponential multiplication, the accumulated free induction decays were subjected to Fourier transformation. Individual spectral peak areas were calculated by computer integration with JEOL software, and the creatine phosphate peak was used as a positional reference $(0$ $\mathrm{ppm})$. The relative amount of each compound was converted to absolute concentration by comparison with the data from an external reference $(20 \mathrm{mM}$ methylene diphosphonate in water) in a spherical bulb. The relative ATP levels were obtained by taking the ratio of the $\beta$-phosphate peak of ATP ( $\beta$-ATP) to the reference peak, and then the $\beta$-ATP/inorganic phosphate peak area ratio $(\beta-\mathrm{ATP} / \mathrm{Pi}$ ratio) was calculated to evaluate in vivo energy metabolism. Beta-ATP / inorganic phosphate ratio represents the high energy state ${ }^{7}$. The intracellular $\mathrm{pH}$ was determined from the chemical shift difference between the Pi peak and the a-phosphate peak of ATP').

In both muscles, rapid depletion of creatine phosphate was followed by a decrease in ATP. These high-energy phosphates disappeared earlier in the soleus than in the EDL. In both muscles, inorganic phosphate showed a marked increase in a biphasic pattern, and sugar phosphate levels also showed significant increases. The NMR-visible total phosphates increased significantly in the soleus during the latter stage of observation. This increase in NMR-visible total phosphates was attributed to an increase in inorganic phosphate. Although the two muscles showed the same initial and final intracellular $\mathrm{pH}(7.21$ and 5.90, respectively), the pattern of intracellular $\mathrm{pH}$ decrease differed between these muscles. The rapid decrease in intracellular $\mathrm{pH}$ in the soleus in the early stage suggested that non-lactic acid acidosis (nonlactic acidosis) plays a significant role in postmortem changes. Although the level of NMR-visible total phosphates during catabolism increased only in the soleus muscle, it is not clear whether this observation was attributable to the use of intact muscles with no myofiber damage. The rapid intracellular $\mathrm{pH}$ decrease observed in the soleus muscle in the early stage cannot be explained by the established theory that the postmortem $\mathrm{pH}$ decrease is caused by lactate formation due to glycolysis. These findings indicated that nonlactic acidosis plays a significant role in the postmortem $\mathrm{pH}$ change. Ravalec et al. ${ }^{105)}$ demonstrated that the improvement of muscular oxidative capacity by training is associated with slight acidosis and ATP depletion in exercising muscles by the in vivo ${ }^{31} \mathrm{P}$ NMR 
technique. Metabolic and mechanical properties of the skeletal muscles of female rats subjected to endurance training on a treadmill were studied by in vivo multistep fatigue test, and ${ }^{31}$ P NMR was used to follow energy metabolism and $\mathrm{pH}$. The oxidative capacity of the skeletal muscles was evaluated from the relationship between ADP calculated from the creatine kinase equilibrium and work and from the rate of phosphocreatine resynthesis following exercise. In trained muscles, ADP production was lower per unit of mechanical performance, showing an improvement of oxidative metabolism. However, the phosphocreatine resynthesis rate was not modified. Slight acidosis and ATP depletion were observed from the beginning of the fatigue test. These modifications suggested changes of the creatine kinase equilibrium favoring mitochondrial ATP production.

In farm animals, investigation of the time course of the catabolism of high energy phosphates in the skeletal muscle is very important to evaluate meat quality ${ }^{4}$. We used female Saanen goats as a model of ruminants and evaluated the goat supraspinatus (slow-twitch muscle : Type I fiber-dominant, representative oxidative energy producing muscle) and tensor fasciae latae (fast-twitch muscle: Type IIB fiber-dominant, representative glycolytic energy producing muscle) muscles using nondestructive ${ }^{31} \mathrm{P}$ NMR spectroscopy. In both muscles, rapid depletion of creatine phosphate was followed by a decrease in ATP. These high energy phosphates disappeared earlier in the supraspinatus than in the tensor fasciae latae. Glycerophosphorylcholine was detected only in the goat supraspinatus muscle. Intracellular $\mathrm{pH}$ decreased faster in the supraspinatus than in the tensor fasciae latae, although the two muscles had the same final intracellular $\mathrm{pH}$. Our findings confirmed that the physiological characteristics of skeletal muscles such as histochemical myofiber type composition or contractile capacities are close- ly related to meat quality, and that type II myofiber-dominant muscles mature more quickly than those dominated by type I myofibers. In both experimental and domestic animals, a rapid decrease in intracellular $\mathrm{pH}$ of type I myofiber-dominant muscles was confirmed $^{4,5)}$. In porcine and bovine skeletal muscles, the ${ }^{31} \mathrm{P}$ NMR technique is also useful to assess postmortem metabolism and evaluate meat quality ${ }^{136)}$. These findings indicated that the ${ }^{31} \mathrm{P}$ NMR method could be used to quantitatively evaluate the muscle energy metabolic characteristics that determine meat quality of domestic animals. Moreover, Geers et al. ${ }^{22}$ used the NMR method to detect halothanesensitive genes in pigs. They estimated the energy metabolism of skeletal muscle tissue of young pigs $(12-18 \mathrm{~kg})$ using in vivo ${ }^{31} \mathrm{P} \mathrm{NMR}$ spectroscopy. Their results, if confirmed with a large number of pigs, might provide new possibilities for selection procedures for leanness because a shift between genotypic and phenotypic variability with respect to halothane susceptibility was observed. Iotti et al. ${ }^{35)}$ used ${ }^{31} \mathrm{P}$ NMR spectroscopy to study in vivo the transport of inorganic phosphate from the cytosol into mitochondria as assessed by the kinetics of inorganic phosphate recovery during ischemia after aerobic exercise. Their results showed that inorganic phosphate transport from the cytosol into mitochondria is active in the absence of ATP biosynthesis and lasts for 30 seconds, possibly as a consequence of the decreased $\mathrm{pH}$ gradient due to transport of inorganic phosphate and $\mathrm{H}^{+}$associated with an inactive electron transport chain during

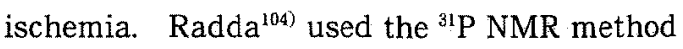
to quantitatively evaluate the capacity of energy metabolism in the skeletal muscles, and demonstrated that skeletal muscle energetics can be studied noninvasively at rest, during exercise and in recovery using ${ }^{31} \mathrm{P}$. NMR. In resting muscle, inorganic phosphate and total cellular phosphate concentration are regulated by $\mathrm{Na}^{+}$-dependent inorganic phosphate 
transport. Insulin was shown to stimulate inorganic phosphate uptake in cultured G-8 muscle cells, in isolated rat soleus muscle, and in human muscle in vivo. Recovery after exercise is entirely oxidative ; the rate of ATP synthesis is largely controlled by ADP, the concentration of which is determined by the creatine kinase equilibrium that includes the concentration of $\mathrm{H}^{+}$. At the onset of aerobic dynamic exercise, ATP is maintained largely by glycolysis, producing lactic acid, and by phosphocreatine breakdown. After vasodilation, ATP synthesis becomes predominantly oxidative. These ${ }^{31} \mathrm{P}$ NMR methods have been developed to observe muscle functions, i.e. contractile functions and energy metabolism, and recently ${ }^{1} \mathrm{H}$ imaging NMR (magnetic resonance imaging: MRI) methods have been developed. MRI revealed not only the morphology of skeletal muscles but also their physiological functions. Ville et al. ${ }^{137)}$ demonstrated that MRI is a useful tool to measure in vivo intramuscular fat content in porcine longissimus muscle. Yamaguchi et al. ${ }^{133)}$ showed that the MRI technique is useful for evaluation of marbling of longissimus muscle of bovine carcasses.

In conclusion, the ${ }^{31} \mathrm{P}$ NMR method is very useful for evaluating the effects of excise on skeletal muscle, for detecting pathogenic genes, and for determining the mechanisms of metabolic disorders. In farm animals, the ${ }^{31} \mathrm{P}$ NMR technique has been used for assessment of muscle physiological characteristics and meat quality ${ }^{4,5,83,136)}$. The MRI technique has also been applied for evaluation of meat quality of farm animals ${ }^{137,138)}$. Such structure-biological techniques will be useful for future analysis of the in vivo physiological properties of skeletal muscles.

\section{Acknowledgments}

The author wishes to thank Mr. Yoshihiro Furuya, Ms. Tomoko Morimoto-Asakawa, Ms. Keiko Kuramitsu, Mr. Makoto Miyamoto, Mr. Kotaro Tamura, Ms. Kozue Uchio and Ms. Miki
Sugimoto for technical assistance, and Drs. Yasuyoshi Azuma, Nobuo Nagano, Hayime Miyamoto, Jean-Alexis Grimaud, Michèle Chevallier, Sylviane Guerret and Alexis Desmoullier for advice throughout the study.

\section{References}

1) Ariano MA, Armstrong RB, Edgerton VR. Hind limb muscle fiber populations of five mammals. J. Histochem. Cytochem., 21 : 51-55. 1973.

2) Armstrong RB, Saubert IV CW, Seeherman $\mathrm{HJ}$, Taylor CR. Distribution of fiber types in locomotory muscles of dogs. Am. J. Anat., 163 : 87-98. 1982.

3) Armstrong RB, Phelps RO. Muscle fiber type composition of the rat hind limb. Am. J. Anat., $171: 256-272.1984$.

4) Azuma Y, Manabe N, Kawai F, Kanamori M, Miyamoto $\mathrm{H}$. Phosphorus-31 nuclear magnetic resonance study of postmortem changes in the intact tissue of goat muscles. Anim. Sci. Technol. (Jpn.), 65 : 416-422. 1994.

5) Azuma $Y$, Manabe $N$, Kawai $F$, Kanamori $M$, Miyamoto $\mathrm{H}$. Phosphorus-31 nuclear magnetic resonance study of energy metabolism in intact slow and fast twitch muscles of rats. J. Anim. Sci., 72 : 103-108. 1994.

6) Bárány $M$, Bárány $K$, Reckard $T$, Volpe A. Myosin of fast and slow muscles of the rabbit. Arch. Biochem. Biophys., 109 : 185-191. 1965.

7) Bárány M, Clonek T. Phosphorus-31 nuclear magnetic resonance of contractile systems. Method. Enzymol., 85 : 624-676. 1982.

8) Beermann DH, Cassens RG, Hausman GJ. A second look at fiber type differentiation in porcine skeletal muscle. J. Anim. Sci.. $46: 125-132$. 1978.

9) Bendal JR, Voyle CA. A study of the histological changes in the growing muscles of becf animals. J. Food Tech., 2 : 259-283. 1967.

10) Brooke MH, Kaiser KK. Muscle fiber types: how many and what kind? Arch, Neurol., 23 : 369-379. 1970.

11) Brooke MH, Kaiser KK. Three 'myosin adenosine triphosphatase' systems: the nature of their pH Iability and sulfhydryl dependence. J. Histochem. Cy tochem., 18: 670-672. 1970.

12) Buche P, Mauron D. Quantitative characterization of muscle fiber by image analysis. Com. Elect. Agr., 16 : 189-217. 1997.

13) Burke RE, Levine DN, Tsairis P, Zajac FE III. 
Physiological types and histochemical profiles in motor units of the cat gastrocnemius. $J$. Physiol., $234: 723-748.1973$.

14) Cassens RG, Marple DN, Eikelenboom G. Animal physiology and meat quality. Adv. Food Res., 21 : 71-155. 1975.

15) Chien YY, Chu NS. Effects of partial and total denervation on the distribution of fiber size of rat soleus muscles: A quantitative computer imaging analysis. Acta Histochem. Cytochem., 28 : 255-261. 1995.

16) d'Albis A, Panaloni C, Bechet J-J. An electrophoretic study of native myosin isozymes and their subunit content. Eur. J. Biochem., $99: 261-272.1979$.

17) d'Albis A, Janmot C, Bechet J-J. Comparison of myosins from the masseter muscle of adult rat, mouse and guinea-pig. Eur. J. Biochem., $156: 291-296.1979$.

18) d'Albis A, Couteaux R, Janmot C, Roulet A. Specific programs of myosin expression in the postnatal development of rat muscles. Eur. J, Biochem., 183 : 583-590. 1989.

19) Davies AS. Postnatal changes in the histochemical fibre types of porcine skeletal muscle. J. Anat., 113: 213-240. 1972.

20) Essén-Gustavsson B. Karlsson A, Lundströme $\mathrm{K}$, Enfält A-C. Intramuscular fat and muscle fibre lipid contents in halothane-gene-free pigs fed high or low protein diets and relation to meat quality. Meat Sci., $38: 269-277.1994$.

21) Geeasee ML. Conversion of muscle to meat. In : Muscle as Food. (Bechtel PJ eds.) 37-102. Academic Press. Orlando. 1986.

22) Geers R, Decanniere C, Rosier A, Ville H, VanHecke P. Vandesande F, Jourquin J. Variability of energy metabolism and nuclear T-3-receptors within the skeletal muscle tissue of pigs different with respect to the halothane gene. J. Anim. Sci., 74 : 717-722. 1996.

23) Geoffrion Y, Rydzy M, Butler KW, Smith ICP, Jarrell HC. The use of immobilized ferrite to enhance the depth selectivity of in vivo surface coil NMR spectroscopy. NMR Biomed., $1: 107-$ 112. 1998.

24) Goto $T$, Iwamoto $H$, Ono $Y$, Nishimura $S$, Takahara H. Distribution of histochemical fibre types in $M$. biceps femoris of cross bred steer (Japanese Black male $\times$ Holstein female). Anim. Sci. Technol. (Jpn.), 64 : 927 929. 1993.

25) Goto $T$, Iwamoto $H$, Ono $Y$, Nishimura $S$, Matsuo K, Nakanishi Y, Umetsu R, Takahara $\mathrm{H}$. Comparative study on the regional compo- sition of fiber types in $M$. longissimus thoracis with different marbling scores for Japanese Black steers. Anim. Sci. Technol. (Jpn.), 65 : 454 . $-463.1994$.

26) Goto $T$, Iwamoto $H$, Ono $Y$, Nishimura $S$, Shigematsu I, Nakanishi $Y$, Umetsu $R$, Takahara $H$. Comparative study on the regional composition of fiber types in the cranial portion of $M$. Biceps femoris in Japanese Black steers. Anim. Sci. Technol. (Jpn.), $66: 62-71$. 1995.

27) Guerret S, Rojkind M, Druguet M, Chvallier M, Grimaud J-A. Immunohistochemical micromethods for the measurement of specific collagen types in human liver biopsies. Coll. Rel. Res. (Matrix), $8: 249-258.1988$.

28) Harrington WF, Rogers ME. Myosin. An. Rev. Biochem., $53:$ 35-73. 1984.

29) Havenith MG, Visser R. Muscle fiber typing in routinely processed skeletal muscle with monoclonal antibodies. Histochemistry, 93: 497-499. 1990.

30) Hoh JFY. Developmental changes in chicken skeletal muscle myosin isozymes. FEBS Lett., $98: 267-270.1979$.

31) Hoh JFY, McGrath PA, White RI. Electrophoretic analysis of multiple forms of myosis in fast-twitch and slow-twitch muscles of the chick. Biochem. J., $157:$ 87-95. 1976.

32) Hoshino $T$, Suzuki A, Yamaguchi $T$, Ohwada S, Ota M. A comparative morphometrical analysis of the amount and distribution of fat within muscles of Japanese Black cattle, Japanese Shorthorn, and their crossbred $\left(F_{1}\right)$ steers. Tohoku J. Agric. Res., 40:57-64. 1990.

33) Ibebunnjo C. Morphologic and morphometric characteristics of limb muscles of the goat. Small Rum. Res., 13 : 277-286. 1994.

34) limura H, Suzuki A. Muscle architecture and myofiber type composition of porcine intrinsic lingual muscle. Tohoku J. Agric. Res., 46 : 1-9. 1995.

35) Iotti S, Lodi R, Gottardi G, Zaniol P, Barbiroli B. Inorganic phosphate is transported into mitochondria in the absence of ATP biosynthesis : An in vivo "P NMR study in the human skeletal muscle. Biochem. Biophys. Res. Com. 225 : 191-194. 1996.

36) Irie M. Determination of Iongissimus muscle area in pig with ultrasonic linear electronic scanner. Aust. J. Anim. Sci., 5 : 229-235. 1992.

37) Irie M, Swatland HJ. Assessment of porcine fat quality by fiber-optic spectrophotometry. 


\section{Quantification of Muscle Properties}

Aust. J. Anim. Sci., 5 : 753-756. 1992.

38) Irie M, Swatland HJ. Relationships between Japanese pork color standards and optical properties of pork before and after frozen storage. Food Res. Int., 25 : 21-30. 1992.

39) Irie M, Sakimoto M. Fat characteristics of pigs fed fish oil diet containg eicosapentaenoic and docosahexaenoic acids. J. Anim. Sci., 70 : 470477. 1992.

40) Irie M. Application and development of ultra sonography for swine. Jpn. J. Swine Sci., 29 : 127-138. 1992.

41) Irie M, Swatland $H_{J}$. Prediction of fluid lossess from pork using subjective and objective paleness. Meat Sci., $33:$ 277-292. 1993.

42) Irie M, Izumo A, Mohri S. Rapid method for determination of water holding capacity of meat. Meat Sci., $42: 95-102.1996$.

43) Irie M. Meat quality and evaluation techniques including optical methods. In : Reproductive Biology Update. (Miyamoto $\mathrm{H}$, Manabe $\mathrm{N}$ eds.) 461-467. Shoukadoh Booksellers Co. Kyoto. 1998.

44) Iwamoto $H$, Takahara $H$, Okamoto M. Fundamental studies on the meat production of the domestic fowl. VII. Postnatal growth of skeletal muscle in some body parts of barred Plymouth Rock chicken. Sci. Bull. Fac. Agr. Kyushu Univ., 30 : 199-136. 1975.

45) Iwamoto $H$, Kawaida $H$, Ono $Y$, Takahara $H$. Breed differences in the distribution of muscle fiber types in fasciculi of porcine psoas major muscle. Jpn. J. Zootech. Sci., $54: 392-400.1983$.

46) Iwamoto $H$, Morita $S$, Ono $Y$, Takahara $H$, Higashiuwatoko $\mathrm{H}$, Kukimoto $\mathrm{T}$, Goto $\mathrm{S}$. A study on the fiber composition of breast and thigh muscles in Satsumadori crossbred broilers. Jpn. J. Zootech. Sci., 55 : 87-94. 1984.

47) Iwamoto $\mathrm{H}$, Ono $\mathrm{Y}, \mathrm{Kawaide} H$, Takahara $\mathrm{H}$. Histochemical fiber composition of longissimus muscle in the Berkshire pigs bred in Kagoshima prefecture, Anim. Sci. Technol. (Jpn.), $60: 261-272.1989$.

48) Iwamoto $H$, Ono $Y$, Goto $T$, Nishimura $S$, Nakanishi Y, Umetsu R, Takahara H. Comparative studies on the composition of muscle fiber types in Japanese Black, Japanese Brown and Holstein steers. Anim. Sci. Technol. (Jpn.), $62: 674-682.1991$.

49) Iwamoto $H$, Hara $Y$, Ono $Y$, Takahara $H$. Breed differences in the histochemical properties of the $M$. Iliotibialis lateralis myofiber of domestic cocks. Brit. Poultry Sci., 33 : 321-328. 1992.
50) Iwamoto $H$, Hara $Y$, Ono $Y$, Takahara $H$. Breed differences in the histochemical properties of the $M$. Pubo-ischio-fernoralis pars medialis myofiber of domestic cocks. Brit. Poultry Sci., $34: 309-322.1993$.

51) Iwamoto $H$, Hara $Y$, Goto $T$, Ono $Y$, Takahara H. Different growth rates of male chicken skeletal muscles related to their histochemical properties. Brit. Poultry Sci., 34 : 925-938. 1993.

52) Iwamoto $H$, Goto $T$, Nishimura $S$, Takahara $H$. Interrelationships between histochemical properties of biopsy muscle materials and beef marbling score in the Japanese Black steers. Anim. Sci. Technol. (Jpn.), 66 : 807-809. 1995.

53) Iwamoto H, Fukumitsu $Y$, Matsuzaki $M$, Takemoto X, Morita S, Takahara H. Comparative studies on the histochemical properties of $M$. iliotibialis lateralis from Kumamoto Chochin crossbred roaster and broiler chickens. Brit. Poultry Sci., 38 : 258-262. 1997.

54) Karlsson A, Enfält A-C, Essén-Gustavsson B, Lundström K, Rydhmer L, Stern S. Muscle histochemical and biochemical properties in relation to meat quality during selection for increased lean tissue growth rate in pigs. $J$. Anim. Sci., 71 : 930-938. 1993.

55) Khan MA. Histochemical characteristics of vertebrate striated muscle: A review. Progr. Histochem. Cytochem., 8 : 1-48. 1976.

56) Klosowski B, Bidwell PK, Klosowska D, Piotrowski J. Microstructure of skeletal muscles of growing calves fed silage-based vs hay-based diets : II. Fibre type distribution. Reprod. Nut. Dev., 32 : 257-263. 1992.

57) Lamed R, Levin Y, Oplatka A. Enzymatic mechanochemistry. I. The interaction of heavy meromyosin with "immobilized adenosine triphosphate". Biochim. Biophy. Acta, 305 : 163171. 1973.

58) Lamed $R$, Oplatka A. Application of immobilized adenosine triphosphate in the study of myosin. Biochemistry, $13: 3137-3142.1974$.

59) Manabe N, Sato E, Watanabe $S$, Ishibashi $T$. The skeletal muscle fiber types of the mammals. I. Nyctereus procynoides, Mustela itatsi, Canis familiaris, Rhinolophus ferrumequinum, Crocidula dsinezumi. J. Mamm. Sci, $40: 89-94.1980$.

60) Manabe $N$, Sato E, Maruyama K, Ishibashi $T$. Histochemical analysis of siseletal muscle fibers in eight species of Japanese amphibians : 1. Enzyme histochemical classification of muscle fibers. Jpn. J. Herpetol., 8 : 112-124. 
1980.

61) Manabe $N$, Sato E, Maruyama $K$, Ishibashi $T$. Histochemical analysis of skeletal muscle fibers in eight species of Japanese amphibians: II. PH stability of myosin adenosine triphosphatase. Jpn. J. Herpetol., 8 : 125-129. 1980.

62) Manabe N, Sato E, Maruyama $K$, Ishibashi $T$. Histochemical analysis of skeletal muscle fibers in five species of Japanese reptiles (Mauremycs japonica, Gekko japonicus, Elaphe climacophora, Rhabdophis tigrinus). Jpn. J. Herpetol, $9: 33-45.1981$.

63) Manabe N, Sato E, Ishibashi T. Histochemical analy sis of skeletal muscle fibers in the Copper Pheasant (Phasianus soemmerringii). Tori, 29 : 109-120. 1981.

64) Manabe $N$, Ishii $T$, Ishibashi $T$. PH stability of myosin adenosine triphosphatase activity of the muscle fibers in the growing cattle, sheep and swine. Jpn. J. Zootech. Sci., 53 : 64-66. 1982.

65) Manabe $N$, Ishibashi $T$, Namikawa $K$, Fukushima $\mathrm{T}$. Difference in fiber diameter of twenty muscles among Japanese Black and Holstein cattle, and their crossbreeds. Mem. Coll. Agr. Kyoto Univ., $119: 63-73.1982$.

66) Manabe $N$, Sato $E$, Izumi $T$, Ishibashi $T$. Histoenzymatic characteristics and the size of skeletal muscle fibers in the Guinea fowl (Numida meleagris). Jpn. J. Ornithol., 37 : 1-16. 1988.

67) Manabe $N$, Ishii $T$, Ishibashi $T$. Histochemical fiber type composition and fiber size in skeletal muscles of the growing cattle, sheep and swine. Mem. Coll. Agr. Kyoto Univ., $131: 27-36$. 1988.

68) Manabe N, Ishibashi T. Miyamoto $H$. Changes of the myofiber types in the masseter muscle of the hypothalamic obese rat. Mem. Coll. Agr. Kyoto Univ., 131 : 37-41. 1988.

69) Manabe N, Chvallier M, Peyrol S, Causse X, Trépo C, Grimaud JA. Beneficial effects of interferon- $\alpha$ therapy on liver fibrosis in chronic non-A, non-B hepatitis : Randomized, doubleblinded, placebo controlled trial. Hepatology, 13 : 966-967. 1990.

70) Manabe N, Guerret S, Chvallier M, Peyrol S, Causse X, Trépo C, Grimaud JA. IFN- $\alpha$ reduces hepatic extracellular matrix deposit in chronic $C$ hepatitis: An immunohistochemical study. J. Hepatol., $13: 48-50.1991$.

71) Manabe N, Ishibashi $T$, Miyamoto H. Slowtwitch myofibers are observed in masseter muscle of the hypothalamic obese rat. Anim.
Sci. Technol. (Jpn.), 64 : 440-447. 1993.

72) Manabe N, Azuma $Y$, Miyamoto H, Kawai F. An in vivo ${ }^{31} \mathrm{P}$ nuclear magnetic resonance study on halocarbon-induced hepatic failure in the mouse. In : Current Physiological Sciences. (Sackmann B eds) 235-238. Oxford University Press. Oxford. 1993.

73) Manabe $N$, Chvallier M, Chossgros $P$, Causse $X$, Guerret S, Trépo C, Grimaud J-A. Interferon$\alpha_{2 b}$ therapy reduces liver fibrosis in chronic non-A, non--B hepatitis : A quantitative histological evaluation. Hepatology, 18 : 1344-1349. 1993.

74) Manabe N, Azuma X, Furuya Y, Kawai F, Kanamori M, Miyamoto $H$. Evaluation of ${ }^{31} \mathrm{P}$ NMR spectroscopy as an indicator of hepatic toxicity in the mouse. J. Envi. Chem., 4:608611. 1994.

75) Manabe N, Furuya $Y$, Nagano N, Miyamoto $H$. Immunohistochemical microquantitation method for type I collagen in kidney histologic section of the rats. J. Vet. Med. Sci., 56 : 147150. 1994.

76) Manabe N, Azuma Y, Furuya Y, Nagano N, Miyamoto $H$. A new immunohistochemical method for quantification of fast-myosis in frozen histologic sections of the rat skeletal muscles. J. Vet. Med. Sci., 56 : 7-13. 1994.

77) Manabe N, Suzuki T, Kuramitsu K, Kuribayashi $N$, Takamatsu $S$, Kojiro $M$, Matuura Y, Miyamura T, Miyamoto H. Apoptosis of hepatocytes highly correlates with liver fibrosis in chronic hepatitis B. Hepatology, 22 : 267-268. 1995.

78) Manabe N, Azuma Y, Furuya Y, Kuramitsu K, Nagano N, Miyamoto H. Immunohistochem. ical microquantification of fast-myosin in frozen histological sections of mammalian skeletal muscles. J. Anim. Sci., 73 : 88-95. 1995.

79) Manabe N, Furuya $Y$, Nagano N, Yagi M, Kuramitsu $\mathrm{K}$, Miyamoto $\mathrm{H}$. Immunohistochemical quantitation for extracellular matrix proteins in rats with glomerulonephritis induced by monoclonal anti-Thy1.1 antibody. Nephron, 71 : 79-86. 1995.

80) Manabe N, Azuma Y, Furuya Y, Kuramitsu K, Kuribayashi $\mathrm{Y}$, Nagano $\mathrm{N}$, Miyamoto $\mathrm{H}$. Immunohistochemical quantification of fastmyosin in frozen histological sections of the goat limb muscles. Anim. Sci., $62: 325-335$. 1996.

81) Manabe N, Kuribayashi Y, Miyamoto M, Kuramitsu K, Azuma Y, Furuya Y, Nagano N, 
Miyamoto H. Immunohistochemical quantification of fast-myosin in frozen histological sections of goat hind limb muscles. Anim. Sci. Technol. (Jpn.), $67:$ 338-352. 1996.

82) Manabe $N$, Suzuki $T$, Kuribayashi $N$, Miyamoto M, Kuramitsu K, Takamatsu S, Kojiro M, Matuura Y, Miyamura T, Miyamoto H. Liver fibrosis is highly correlated with hepatocellular apoptosis and transforming grow th factor $-\beta 1 \mathrm{mRNA}$ expression in chronic hepatitis B. Hepatology, 24 : 366-367. 1996.

83) Manabe N, Sugimoto M, Azuma Y, Taketomo N, Yamashita A, Tsuboi H, Tsunoo A, Kinjo N, Nian-Lai H, Miyamoto H. Effect of the mycelial extract of cultured cordyceps sinensis on in vivo hepatic energy metabolism in the mouse. J. Pharmacol., $70:$ 85-88. 1996.

84) Manabe N, Hata H, Suzuki T, Matuura Y, Miyamura $T$, Miyamoto M, Tamura K, Kojiro M, Takamatsu S, Miyamoto H. Hepatitis C virus infection is highly correlated with hepatocellular apoptosis and transforming growth factor- $\beta 1$ mRNA expression in chronic hepatitis C. Hepatology, $26: 555.1997$.

85) Manabe N, Azuma Y, Miyamoto M, Kuramitsu K, Furuya $Y$, Nagano N, Miyamoto H. Quantitative physiology estimated by histochemical and structure-biological measurement. In : Reproductive Biology Update. (Miyamoto $\mathrm{H}$, Manabe N eds.) 469-481. Shoukadoh Booksellers Co. Kyoto. 1998.

86) Miyamoto M, Manabe N, Kuramitsu K, Kuribayashi $Y$, Tamura K, Furuya $Y$, Nagano $\mathrm{N}$, Fukumoto M, Miyamoto $\mathrm{H}$. Lectin histochemistry in rat liver fibrosis induced by heterologous serum sensitization. J. Vet. Med. Sci., $59: 681-687.1997$.

87) Miyamoto $M$, Manabe N, Uchio K, Kuramitsu K, Tamura K, Furuya Y, Nagano N, Miyamoto H. Characteristics of lectin staining patterns assessed by a modified sensitive thermomethod in rat livers with heterologous seruminduced fibrosis. J. Vet. Med. Sci., 60 : 953-960. 1998.

88) Miyamoto $M$, Manabe $N$, Kuramitsu $K$, Kuribayashi Y, Tamura K, Furuya Y, Nagano $N$, Fukumoto $M$, Miyamoto $H$. Lectin histochemistry in fibrotic liver disease. In : Reproductive Biology Update. (Miyamoto $\mathrm{H}$, Manabe N eds.) 483-490. Shoukadoh Booksellers Co. Kyoto. 1998.

89) Morikawa $S$, Inubushi $T$, Takahashi $K$, Terada $\mathrm{Y}$, Iwata S, Ozawa K. Glucose and energy me- tabolism in rat liver after ischemic damage assessed by ${ }^{13} \mathrm{C}$ and ${ }^{31} \mathrm{P}$ NMR spectroscopy. J. Surg. Res., 63 : 393-399. 1996.

90) Nagano N, Yagi M, Kato S, Furuya Y, Miyata $S$, Manabe N. Renal responses to atrial natriuretic peptide (ANP) in rats with nonoliguric acute renal failure induced by cisplatin. J. Vet. Med. Sci., 57 : 997-1002. 1995.

91) Nishiyama $Y$, Manabe N, Ooshima A, Miyatake S, Adachi T, Takahashi K, Kanda Y, Hiai H, Fukumoto M. A sporadic case of EhlersDanlos syndrome type IV : Diagnosed by a morphometric study of collagen content. Pathol. Internat., 45:524-529. 1995.

92) Ono $Y$, Iwamoto $H$, Takahara $H$. The effect of androgen on histochemical fiber composition of $M$. Semispinalis cervicis in the cock. Jpn. J. Zootech. Sci., 55 : 958-964. 1984.

93) Ono $Y$, Iwamoto $H$, Takahara $H$. Allometry of body weight, skeletal muscle weight and muscle fiber diameter in the chick. Jpn. J. Zootech. Sci., 60 : 958-964. 1989.

94) Ono $Y$, Iwamoto H, Takahara H. Degeneration of type I fibers in the chick brachial muscles during postnatal development. Anim. Sci. Technol. (Jpn.), $63:$ 341-348. 1992.

95) Ono $Y$, Goto $T$, Nishimura $S$, Iwamoto $H$, Takahara $H$. The effect of denervation on the degenerative process of type I fibers in the biceps brachii muscle of the chick. Anim. Sci. Technol. (Jpn.), $63:$ 805-808. 1992.

96) Ono $Y$, Iwamoto $H$, Takahara $H$. The relationship between muscle growth and the growth of different fiber types in the chicken. Poul. Sci., $72:$ :568-576. 1993 .

97) Ono Y, Solomon MB, Evock-Clover CM, Steele NC, Maruyama $K$. Effects of porcine somatotropin administration on porcine muscles located within different regions of the body. J. Anim. Sci., 73 : 2282-2288. 1995.

98) Ono Y, Solomon MB, Elasser TH, Rumsey TS, Moseley WM. Effects of Synovex-S and recombinant bovine growth hormone (Somavubove ${ }^{3}$ ) on growth responses of steers :II. Muscle morphology and proximate composition of muscles. J. Anim. Sci., 74 : 2929-2934. 1996.

99) Peter JB, Narnard RJ, Edgerton VR, Gillespie CA, Stempel KE. Metabolic profiles of three fiber types of skeletal muscle in guinea pigs and rabbits. Biochemistry, 11 : 2627 2633. 1972.

100) Pette D, Staron RS. Cellular and molecular diversities of mammalian skeletal muscle 
fibers. Rev. Physiol. Biochem. Pharmacol., 116 : 1-76. 1990.

101) Peuker H, Pette D. Quantitative analyses of myosin heavy-chain mRNA and protein isoforms in single fibers reveal a pronounced fiber heterogeneity in normal rabbit muscles. Eur. J. Biochem., 247 : 30-36. 1997.

102) Picard B, Leger J, Robelin J. Quantitative determination of type I myosin heavy chain in bovine muscle with anti myosin monoclonal antibodies. Meat Sci., 36 : 333-343. 1994.

103) Pullen AH. The distribution and relative sizes of fibre types in the extensor digitorum longus and soleus muscles of the adult rat. J. Anat., $123: 467-486.1977$.

104) Radda GK. Control of energy metabolism during muscle contraction. Diabetes, $45: 88-92$. 1996.

105) Ravalec X, Le Tallec N, Carre F, D Certaines JD, Le Rumeur E. Improvement of muscular oxidative capacity by training is associated with slight acidosis and ATP depletion in exercising muscles. Muscle Nerve, $19: 355-361$. 1996.

106) Reiser PJ, Moss RL, Giulian GG, Greaser ML. Shortening velocity in single fibers from adult rabbit soleus muscles is correlated with myosin heavy chain composition. J. Biol. Chem., 260 : 9077-9080. 1985.

107) Robe GH, Xiong YL. Phosphates and muscle fiber type influence thermal transition in porcine salt-soluble protein aggregation. J. Food Sci., 57 : 1304-1307. 1992.

108) Staron RS, Pette D. Correlation between myofibrillar ATPase activity and myosin heavy chain composition in rabbit muscle fibers. Histochemistry, $86: 19-23.1986$.

109) Suzuki A. Histochemical classification of individual skeletal muscle fibers in the sheep. I. On $M$. semitendinosus, $M$. longissimus dorsi, $M$. psoas major, $M$. latissimus dorsi and $M$. gastrocnemius. Jpn. J. Zootech. Sci., $42: 39-54$. 1971.

110) Suzuki A. Histochemical classification of individual skeletal muscle fibers in the sheep. II. On $M$. serratus ventralis, $M$. supraspinatus, $M$. infraspinatus, $M$. semimembranosus and $M$. triceps brachii (Caput longum). Jpn. J. Zootech. Sci., 42: 463-473. 1971.

111) Suzuki A. Histochemical observations of individual skeletal muscle fibers in starved sheep. Jpn. J. Zootech. Sci., 44: 50-58, 1973.

112) Suzuki A, Tamate H. Histochemical classific- ation of skeletal muscle fibers in the cattle. Acta Histochem. Cy tochem., 7 : 319-327. 1974.

113) Suzuki A. The pH stability of myofibrillar adenosine triphosphatase of five fiber types in skeletal muscles of the sheep and cattle. Jpn. J. Zootech. Sci., 47 : 95-103. 1976.

114) Suzuki A. A comparative histochemical study of the masseter muscle of the cattle, sheep, swine, dog, guinea pig, and rat. Histochem., 51 : 121-131. 1977.

115) Suzuki A. Classification of skeletal muscle fibers in domestic animals and their functional significance. Jpn. J. Zootech. Sci., 48 : 183-191. 1977.

116) Suzuki A, Ohwada S, Tamate H. The presence of intrafiber fat droplets in muscle fiber types and the distribution and size of these fiber types in four muscles of Japanese Black and Holstein cattle. Jpn. J. Zootech. Sci., $49: 262$ 269. 1978.

117) Suzuki A, Cassens RG. A histochemical study of myofiber types in muscle of the growing pig. J. Anim. Sci., 51 : 1449-1461. 1980.

118) Suzuki A, Tsuchiya $T$, Takahashi $Y$, Tamate $H$. Histochemical properties of myofibers in longissimus muscle of common dolphines (Delphinus delphis). Acta Histochem. Cytochem., $16: 223-231.1983$.

119) Suzuki A, Tsuchiya $T$, Ohwada S, Tamate $H$. Distribution of myofiber types in thigh muscles of chickens. J. Morphol., $185: 145^{-154}$. 1985 b.

120) Suzuki A, Tamate H. Muscle fiber types classified on the basis of histochemical enzyme activity and their functional and changeability. Prog. Vet. Sci., 1985 : 1-27. 1985.

121) Suzuki A. A histochemical change in myofibers of sheep muscle in refrigeration. Tohoku J. Agric. Res., 36 : 3-4. 1986.

122) Suzuki A, Tamate H. Distribution of myofiber types in the hip and thigh musculature of sheep. Anat. Rec., 221 : 494-502. 1988.

123) Suzuki A. Myofiber atrophy and histochemical changes in thigh muscles of a lame goat with foot rot. Tohoku J. Agric. Res., 38 : 1-10. 1988.

124) Suzuki A. Inconsistency of reactivity for acidstable myosin ATPase in subtypes of type I myofibers in equine, porcine, and caprine muscles. Tohoku J. Agric. Res., $39: 73-79.1989$.

125) Suzuki A. Histochemical properties of the masseter muscle in horses and goats. Tohoku J. Agric. Res., $40:$ 1-2. 1990.

126) Suzuki A. Composition of myofiber types in 


\section{Quantification of Muscle Properties}

limb muscles of the house shrew (Suncus murinus) : Lack of type I myofibers. Anat. Rec., $228: 23-30.1990$.

127) Suzuki A, Hayama S. Histochemical classification of myofiber types in the triceps surae and flexor digitorum superficialis muscle of Japanese macaques. Acta Histochem. Cy tochem., 24 : 323-328. 1991.

128) Suzuki A. Composition of myofiber types in the pectral girdle musculature of sheep. Anat. Rec., 230 : 339-346. 1991.

129) Suzuki A, Hayama S. Individual variation in myofiber type composition in the triceps surae and flexor digitorum superficialis muscles of Japanese macaques. Anthropol. Sci., 102 : S 127-138. 1994.

130) Suzuki A. Differences in distribution of myofiber types between the supraspinatus and infraspinatus muscles of sheep. Anat. Rec., $242:$ 483-490. 1995.

131) Suzuki A. Adaptation of skeletal myofiber types to arboreality. Primate Res., 12 : 133-146. 1996.

132) Suzuki A, Yamadera $Y$, Kido K, Watanabe K. Sarcomere shortening and contraction nodes in stretched-restrained ovine myofibres during post mortem storage. Meat Science, 46 : 339-348. 1997.

133) Suzuki A, Watanabe $K$, Yoshida $Y$, Kido K, Konno $T$, Ohwada S. Possibility of artificial increased in type I myofibers associated with palatability of meat and fatty change in ovine muscle. In : Reproductive Biology Update. (Miyamoto H, Manabe $\mathrm{N}$ eds.) 451-459. Shoukadoh Booksellers Co. Kyoto. 1998.

134) Termin A, Staron RS., Pette D. Changes in myosin heavy chain isoforms during chronic low-frequency stimulation of rat fast hind limb muscles. Eur. J. Biochem., $186: 749-754$. 1989.

135) Termin A, Staron RS, Pette D. Myosin heavy chain isoforms in histochemically defined fiber types of rat muscle. Histochemistry, $92: 453$ 457. 1989.

136) Uhein P, Liptaj T. ${ }^{\text {st }}$ P NMR study of postmor tem metabolism in porcine and bovine muscles. Gen. Physiol. Biophys., $10: 83-93$ 1991.

137) Ville $H$, Rombouts $G$, Van-Hecke $P$, Perremans $S$, Maes G, Spincemaille G, Geers R. An evalua tion of ultrasound and nuclear magnetic reso. nance spectroscopy to measure in vivo in tramuscular fat content of longissimus muscle of pigs. J. Anim. Sci., 75 : 2942-2949. 1997.

138) Yamaguchi $T$, Ozutsumi $K$, Ohwada $S$, Yoneya S, Suzuki A, Matsumoto K, Sakamoto K, Yamaki K, Yoshitake M, Satoh K, Hoshino T. Improved evaluation by magnetic resonance imaging (MR Imaging) on marbling in $M$. Longissimus thoracis of carcasses of beef cattle. Anim. Sci. Technol. (Jpn.), 63 : 942-946, 1992. 